\title{
PENGARUH PENDIDIKAN GIZI ANEMIA TERHADAP PENINGKATAN \\ PENGETAHUAN PADA ANAK REMAJA SMA NEGERI 21 MAKASSAR
}

\section{THE EFFECT OF NUTRITION EDUCATION OF ANEMIA AMONG IMPROVEMENT OF KNOWLEDGE IN ADOLESCENTS SMA NEGERI 21 MAKASSAR}

\author{
Darmayanti Waluyo ${ }^{1}$, Healthy Hidayanty ${ }^{2}$, Arifin Seweng ${ }^{3}$ \\ ${ }^{1}$ Bagian Epidemiology, Program Studi Kesehatan Masyarakat, STIK Avicenna Kendari \\ ${ }^{2}$ Bagian Gizi, Fakultas Kesehatan Masyarakat, Universitas Hasanuddin \\ ${ }^{3}$ Bagian Biostatistik, Fakultas Kesehatan Masyarakat Universitas Hasanuddin
}

\begin{abstract}
Alamat Korespondensi : Darmayanti Waluyo, Fakultas Kesehatan Masyarakat Universitas
Hasanuddin, Makassar, 90154, Hp: 082190900345, Email:

darmayanti218@gmail.com
\end{abstract}

\begin{abstract}
ABSTRAK
Anemia merupakan keadaan jumlah eritrosit atau kadar $\mathrm{Hb}$ dalam darah kurang dari normal $(12 \mathrm{~g} / \mathrm{dl})$ pada remaja perempuan $>15$ tahun. Penelitian ini bertujuan untuk menilai perbedaan pengetahuan sebelum dan sesudah intervensi pendidikan gizi anemia pada remaja kelas X di SMA Negeri 21 Makassar. Penelitian ini adalah penelitian Quasy-experiment dengan desain penelitian "Pretest-Posttest with Control Group". Dalam penelitian ini kelompok intervensi diberikan pendidikan gizi melalui penyuluhan, leaflet dan media social (WA), sedangkan untuk kelompok kontrol diberikan pendidikan gizi hanya melalui leaflet. Sampel dalam penelitian ini adalah sebagian dari populasi siswa putri yang memenuhi kriteria inklusi penelitian yang dibagi ke dalam 2 kelompok yaitu kelompok intervensi dan kelompok kontrol masing-masing jumlah sampel 24 orang tiap kelompok. Hasil penelitian menunjukkan bahwa pada kelompok intervensi dengan nilai $p$ value $0,000<0,05$ ada perbedaan tingkat pengetahuan sebelum dan setelah diberikan intervensi pendidikan gizi anemia. Sementara pada kelompok kontrol dengan nilai $\mathrm{p}$ value $0,001<0,05$ yang berarti ada perbedaan tingkat pengetahuan sebelum dan setelah diintervensi pendidikan gizi anemia. Sementara itu pada kedua kelompok sebelum mendapatkan intervensi pendidikan gizi anemia diperoleh nilai $\mathrm{p}$ value $0,289>0,05$ yang berarti tidak ada perbedaan tingkat pengetahuan pada kedua kelompok, sedangkan setelah mendapatkan intervensi pendidikan gizi anemia di dapatkan nilai value $\mathrm{p}$ value $0,000<0,05$ yang berarti ada perbedaan tingkat pengetahuan pada kedua kelompok. Terdapat perbedaan tingkat pengetahuan setelah dilakukan intervensi pendidikan gizi anemia pada kedua kelompok, dimana kelompok intervensi lebih tinggi peningkatan pengetahuan dengan rata-rata pengetahuan meningkat 2,88 dibandingkan pada kelompok kontrol.
\end{abstract}

Kata Kunci: Anemia, Pendidikan Gizi, Pengetahuan.

\begin{abstract}
Anemia is a state of erythrocytes or less than normal $(12 \mathrm{~g} / \mathrm{dl})$ of $\mathrm{Hb}$ in a female adolescent $>15$ years. This study aimed to assessing differences in knowledge before and after anemia nutrition education intervention in adolescents at SMA Negeri 21 Makassar. This research is Quasy-experiment research with research design "Pretest-Posttest with Control Group". In this study the intervention group was given nutrition education through counseling, leaflet and social media (WA), while for control group was given nutrition education only through leaflet. The sample in this study was a portion of the female student population that meets the inclusion research criteria divided into 2 groups namely the intervention group and the control group of each sample number of 24 people per group. The results showed that in the intervention group with $p$ value $0.000<0.05$ there was a difference in the level of knowledge before and after being given anemia nutrition education intervention. While in control group with $p$ value 0,001 $<0,05$ which means there is difference of knowledge level before and after intervention of nutrition education anemia. Meanwhile, in both groups before getting an intervention of nutrition anemia education obtained $p$ value $0.289>0.05$ which means there is no difference in knowledge level in both groups, whereas after getting intervention of nutrition education anemia got value $p$ value $0.000<0,05$ means there is a difference in the level of knowledge in both groups. There is a difference in the level of knowledge after the intervention of anemia nutrition education in the two groups, where the intervention group higher knowledge improvement with the average knowledge increased 2.88 compared to the control group.
\end{abstract}

Keywords: Anemia, Nutrition Education, Knowledge. 


\section{PENDAHULUAN}

Pemenuhan kebutuhan zat gizi pada masa remaja perlu diperhatikan karena terjadinya peningkatan kebutuhan zat gizi untuk mendukung pertumbuhan, perkembangan fisik dan psikis. Perubahan gaya hidup dan kebiasaan makan pada remaja mempengaruhi kebutuhan dan asupan zat gizi (Hardinsyah, 2017).

Masalah gizi dan kesehatan yang dihadapi pada masa remaja salah satunya adalah anemia. Remaja perempuan beresiko lebih tinggi dibandingkan remaja laki-laki, karena remaja perempuan mengalami menstruasi setiap bulan sehingga banyak kehilangan zat besi. Anemia merupakan keadaan jumlah eritrosit atau kadar $\mathrm{Hb}$ dalam darah kurang dari normal (12 g/dl). Hal tersebut menyebabkan penurunan kemampuan $\mathrm{Hb}$ dan eritrosit membawa oksigen keseluruh tubuh, sehingga tubuh menjadi cepat Lelah dan lemas. Penyebab anemia pada remaja perempuan antara lain: menstruasi, pendarahan hebat, kekurangan zat gizi (besi, folat, protein), leukemia, dan penyakit kronis. Tanda-tanda anemia antara lain lemah, letih, lesu, kurang bergairah dalam beraktivitas sehari-hari dan sesak (Hardinsyah, 2017).

$$
\text { Prevalensi Anemia di Propinsi }
$$

Sulawesi Selatan berdasarkan Riskesdas 2007 pada wanita (>15 tahun) sebesar 10,3\% (Litbangkes, 2007). Berdasarkan studi pendahuluan di SMA Negeri 21 Makassar didapatkan prevalensi anemia sebesar 31,5\% siswa Kelas X mengalami anemia.

Beberapa penelitian yang mendukung bahwa dengan pendidikan gizi tentang anemia dapat meningkatkan pengetahuan antara lain penelitian yang dilakukan oleh Kaur et al (2011), menunjukkan hasil penelitian pendidikan gizi adalah satu hal yang tepat, efektif dan berkelanjutan untuk mencegah anemia defisiensi besi. Penelitian lain yang menyatakan pendidikan gizi diperlukan untuk pencegahan anemia adalah penelitian yang dilakukan oleh Karmaker et al (2014), melakukan penelitian pada 176 remaja di Bengal Barat menyatakan bahwa ada peningkatan yang signifikan pada pengetahuan tentang anemia yang mengikuti program pendidikan gizi $(\mathrm{df}=20,241(175))$, dengan $\mathrm{p}<0,0001$. Penelitian ini bertujuan untuk menilai perbedaan pengetahuan sebelum dan sesudah intervensi pendidikan gizi anemia pada remaja kelas $\mathrm{X}$ di SMA Negeri 21 Makassar.

\section{METODE}

\section{Lokasi dan Waktu Penelitian}

Lokasi Penelitian dilaksanakan di SMA Negeri 21 Makassar Waktu Penelitian mulai dari bulan Agustus hingga September 2017.

\section{Desain dan Variabel Penelitian}

Penelitian ini adalah penelitian Quasyexperiment dengan desain penelitian "PretestPosttest with Control Group". Dalam penelitian ini kelompok intervensi diberikan pendidikan gizi melalui penyuluhan, leaflet dan media social (WA), sedangkan untuk kelompok kontrol diberikan pendidikan gizi hanya melalui leaflet.

\section{Populasi dan Sampel}

Populasi dalam penelitian ini adalah keseluruhan siswa kelas X SMA Negeri 21 Makassar. Sampel dalam penelitian ini adalah 
sebagian dari populasi siswa putri yang memenuhi kriteria inklusi penelitian yang dibagi ke dalam 2 kelompok yaitu kelompok intervensi dan kelompok kontrol masingmasing jumlah sampel 24 orang tiap kelompok. Teknik pengambilan sampel yaitu non random (Non Probability Sampling) dengan cara penarikan accidental sampling.

\section{Pengumpulan Data}

Metode pengambilan data dengan menggunakan kuesiner untuk menilai pengetahuan (pretest dan posttest)

\section{Analisis Data}

Data dikumpulkan untuk diedit dan di coding, kemudian data karakteristik dan data pengetahuan dianalisis menggunakan SPSS for windows 21 .

\section{HASIL}

\section{Karakteristik Responden}

Pada tabel 1 menunjukkan bahwa mayoritas responden berumur 15 berjumlah 15 orang $(62,5 \%)$ pada kelompok intervensi, sedangkan pada kelompok kontrol mayoritas responden berumur 16 tahun 14 orang (58,3\%). Berdasarkan pendidikan ayah responden mayoritas berpendidikan SMA berjumlah 10 orang $(41,7 \%)$ pada kelompok intervensi, sedangkan pada kelompok kontrol mayoritas berpendidikan $\mathrm{S} 1$ berjumlah 10 orang $(41,7 \%)$. Berdasarkan pendidikan ibu mayoritas adalah 12 orang (50 \%) pada kelompok intervensi, dan pada kelompok kontrol adalah SMA berjumlah 14 orang $(58,3 \%)$. Berdasarkan pekerjaan ayah, mayoritas adalah PNS sejumlah 11 orang $(45,8 \%)$ pada kelompok intervensi sedangkan pada kelompok kontrol mayoritas pekerjaan ayah Swasta sejumlah 70 orang $(70,8 \%)$. Berdasarkan pekerjaan ibu, mayoritas pada kelompok intervensi adalah Ibu Rumah Tangga (IRT) sebanyak 14 orang $(58,3 \%)$, dan mayoritas pada kelompok kontrol adalah Ibu Rumah Tangga (IRT) sebanyak 16 orang $(66,7 \%)$. Berdasarkan pendapatan ayah pada kelompok intervensi mayoritas adalah lebih dari Rp.3.100.000 sebanyak 11 orang $(45,8)$, sedangkan pada kelompok kontrol mayoritas diatas Rp3.100.000 sejumlah 9 orang $(37,5 \%)$. Sementara berdaasarkan pendapatan ibu, pada kelompok intervensi mayoritas dibawah Rp1.000.000 sebanyak 18 orang (75\%), dan pada kelompok kontrol dibawah Rp. 1.000 .000 sejumlah 20 orang $(83,3 \%)$.

\section{Distribusi Responden Berdasarkan Pengetahuan Sebelum dan Sesudah Pendidikan Gizi Anemia pada Kelompok} Intervensi dan Kontrol

Tabel 2 menunjukkan bahwa distribusi responden berdasarkan pengetahuan sebelum dan sesudah pendidikan gizi anemia pada kedua kelompok mayoritas pengetahuan responden sebelum intervensi adalah pengetahuan kurang, dimana pada kelompok intervensi sebanyak 14 orang $(58,3 \%)$, dan pada kelompok kontrol sebanyak 16 orang $(66,7 \%)$, sedangkan setelah mendapatkan pendidikan gizi anemia pada kedua kelompok pengetahuan responden terbanyak adalah pengetahuan cukup, dimana pada kelompok intervensi sebanyak 22 orang $(91,7 \%)$, dan pada kelompok kontrol pengetahuan responden adalah sebanyak 13 orang $(54,2 \%)$. Jika dilihat dari tabel, kelompok intervensi menunjukkan peningkatan yang lebih baik dibandingkan kelompok kontrol. 
Analisis Pengetahuan Sebelum dan Sesudah

Pendidikan Gizi Anemia Pada Kelompok

\section{Intervensi Dan Kontrol}

Tabel 3 menunjukkan bahwa pada kelompok intervensi dengan nilai $\mathrm{p}$ value $0,000<$ 0,05 ada perbedaan tingkat pengetahuan sebelum dan setelah diberikan intervensi pendidikan gizi anemia. Sementara pada kelompok kontrol dengan nilai $p$ value $0,001<0,05$ yang berarti ada perbedaan tingkat pengetahuan sebelum dan setelah diintervensi

$$
\text { pendidikan gizi anemia. }
$$

Berdasarkan uji Mann Whitney pada kedua kelompok sebelum mendapatkan intervensi pendidikan gizi anemia diperoleh nilai $p$ value $0,289>0,05$ yang berarti tidak ada perbedaan tingkat pengetahuan pada kedua kelompok, sedangkan dilihat dari selisih nilai rata-rata (delta) pada kedua kelompok di dapatkan nilai value $\mathrm{p}$ value $0,005<0,05$ yang berarti ada perbedaan tingkat pengetahuan pada kedua kelompok. Berdasarkan rata-rata peningkatan pengetahuan diketahui bahwa kelompok intervensi memiliki rata-rata peningkatan yang lebih besar yakni 2,88 dibandingkan dengan rata-rata peningkatan pengetahuan pada kelompok kontrol.

\section{PEMBAHASAN}

Hasil penelitian terhadap perubahan tingkat pengetahuan responden menunjukkan bahwa setelah dilakukan intervensi selama 1 bulan, maka pada kelompok yang diberi intervensi menunjukkan perubahan yang lebih baik secara kuantitas dibandingkan kelompok kontrol walaupun di kelompok kontrol juga menunjukkan adanya perubahan distribusi pengetahuan sampel.
Peningkatan level pengetahuan subjek tentunya tidak terlepas dari efek pemberian intervensi berupa pendidikan gizi, pemberian leaflet dan media sosial. Pemberian pendidikan gizi bisa menjadi pemicu meningkatnya pengetahuan siswa tentang gizi yang nantinya akan dapat mempengaruhi perilaku siswa dalam mengkonsumsi makanan sumber zat besi dan mengubah kebiasaan makan siswa dari pola makan yang kurang baik.

Beberapa penelitian menunjukkan hasil yang sejalan dengan teori diatas bahwa pendidikan gizi dapat merubah perilaku pada remaja khususnya yang berkaitan dengan perilaku pencegahan anemia. Penelitian Kaur et al (2011), menunjukkan hasil penelitian pendidikan gizi adalah satu hal yang tepat, efektif dan berkelanjutan untuk mencegah anemia defisiensi besi. Penelitian lain yang menyatakan pendidikan gizi diperlukan untuk pencegahan anemia adalah penelitian yang dilakukan oleh Karmaker et al (2014), yang melakukan penelitian pada 176 remaja di Bengal Barat, yang menyatakan bahwa ada peningkatan yang signifikan pada pengetahuan tentang anemia yang mengikuti program pendidikan gizi $(\mathrm{df}=20,241$ (175)), dengan $\mathrm{p}<0,0001$. Yussoff et al (2012), menemukan diawal intervensi lebih dari 50\% subjek remaja putri mempunyai pengetahuan yang buruk mengenai anemia tetapi setelah dilakukan intervensi pendidikan gizi berupa pembagian brosur, pemutaran video, diskusi dan poster selama 3 bulan terjadi peningkatan pengetahuan dan sikap yang signifikan. Dwiriani, dkk (2011) menyatakan bahwa intervensi pendidikan gizi signifikan meningkatkan 28,6 skor pengetahuan. Sefaya 
\& Rahayuning (2017) menunujukkan kenaikan tingkat pengetahuan gizi 54,3\% dengan $\mathrm{p}$ value $0,048 \quad(<0,05)$ terdapat perbedaan tingkat pengetahuan setelah mendapatkan intervensi pendidikan gizi. Zulaekah (2012) menyatakan pengetahuan gizi mengalami peningkatan setelah intervensi pendidikan gizi dengan media booklet. Penelitian yang dilakukan oleh Savita (2013) juga menyatakan edukasi menunjukkan dalam satu bulan kemudian, tingkat pengetahuan menunjukkan 95,51\% kategori tinggi dan 4,49\% sedang, hal ini menunjukkan pendidikan gizi meningkatkan pengetahuan menjadi lebih baik. Pada penelitian Jalambo (2017) pengetahuan remaja perempuan meningkat secara signifikan setelah intervensi pendidikan gizi, karena persentase pengetahuan yang baik (50\%) adalah $22,7 \%$ intervensi pendidikan pra-nutrisi, dan meningkat menjadi $90,9 \%$ pasca intervensi ( $p$ $<0,001)$ pada kelompok intervensi. Penelitian Silalahio dkk (2016) menunjukkan hasil pskor pengetahuan meningkat dari $62,39 \pm 12,05$ menjadi 72,31 $\pm 17,01$ dengan pvalue $<0,05$ ada perbeadaam pengetahuan sebelum dan sesudah pendidikan gizi. Penelitian Harryono (2014) menyatakan terdapat pengaruh pendidikan anemia gizi audio visual tanpa atau dengan leaflet dalam meningkatkan pengetahuan anemia gizi pada remaja putri.

Dalam kondisi ekonomi sulit di Indonesia saat ini maka pendidikan gizi merupakan intervensi yang tepat dalam mengatasi anemia pada remaja. Hasil pada penelitian ini juga dapat menjadi acuan untuk pelaksanaan pendidikan gizi bagi kalangan remaja karena terbukti pendidikan gizi yang diberikan selama 1 bulan dapat meningkatkan pengetahuan, mengubah asupan dan pola kebiasaan makan subjek.

\section{KESIMPULAN DAN SARAN}

Dalam penelitian ini disimpulkan bahwa ada perbedaan tingkat pengetahuan yang dapat dilihat dari selisih nilai-rata-rata (delta) pada kedua kelompok dengan $\mathrm{p}$ value $0,005<0,05$, dimana kelompok intervensi lebih tinggi peningkatan pengetahuan dengan rata-rata pengetahuan meningkat 2,88 dibandingkan pada kelompok kontrol. Untuk penelitian selanjutnya disarankan untuk memberikan jenis pendidikan gizi anemia lain, sehingga dapat di ketahui jenis-jenis pendidikan gizi anemia yang lebih baik.

\section{DAFTAR PUSTAKA}

Badan Penelitian Dan Pengembangan Kesehatan. (2008). Riset Kesehatan Dasar (Riskesdas 2007). Jakarta: Depkes RI.

Dwiriani, C dkk. 2011. Pengaruh Pemberian Zat Multi Gizi Mikro Dan pendidikan Gizi Terhadap pengetahuan Gizi, Pemenuhan Zat Gizi Dan Status Besi Remaja Putri. Journal of Nutrition And Food, 6(3); 171-177.

Hardinsyah. (2017). Ilmu Gizi Teori Dan Aplikasi. Jakarta: EGC.

Haryono, D dkk. 2014. Pengaruh Pendidikan Anemia Gizi Audio Visual Dan Leaflet Terhadap Tingkat Pengetahuan dan Perilaku Mengkonsumsi Tablet $\mathrm{Fe}$ Serta Kadar Hemoglobin Pada Remaja Putri. Jurnal Gizi Dan Kesehatan Vol 1 No 2. 
Karmaker et al. (2014). Effectiveness of Intervention on knowledge of Anaemia Among School Going Adolescent Girls in A Village of West Bengal. International Journal of Medical Science and Clinical Invention. Vol 1 issue 4. Page: 140-143.

Kaur M. (2011). Impact Of Nutrition Education In Reducing Iron Deficiency Anemia In Adolescent Girls. Indian Journal of Fundamental and Applied Life Sciences. Vol. 1 (4) October- December, pp.222-228.

Jalambo, M et al. (2017). Improvement In Knowledge Attitude And Practice Of Iron Deficiency Female Adolescent After Nutrition Education Intervention. Global Journal Of Health Science: Vol 9 No 7.

Savita et al. (2013). Impact Of Education Nutrition On Nutrition Knowledge Of Iron Deficiency Anaemia Among post Adolescent Girls. Asian J. Dairy \& Food. Res. 32(3); 214-219.

Sefaya, S \& Rahayuning. (2017). Pengaruh Pendidikan Gizi Terhadap Pengetahuan Gizi Dan Tingkat Kecukupan Gizi Terkait Pencegahan Anemia Remaja (Studi Pada Kelas XI) SMA Teuku Umar Semarang. Jurnal Kesehatan Masyarakat (e-Journal) Vol 5 No 1: Januari.

Silalahio dkk. (2016). Potensi Pendidikan Gizi Dalam Meningkatkan Asupan Gizi Pada Remaja Putri Yang Anemia di Medan. Jurnal Kesehatan Masyarakat. KESMAS 11(2).
Yusoff et al. (2012). Nutrition education and knowledge, attitude and hemoglobin status of Malaysian adolescents. Southeast Asian Journal of Tropical Medicine and Public Health. 43(1), p.192.

Zulaekah, S. (2012). Pendidikan Gizi Dengan Media Booklet Terhadap Pengetahuan Gizi. Jurnal Kesehatan Masyarakat, KESMAS 7(2); 127-133.

Profil Dinkes Kota Palopo. (2016). Profil Dinas Kesehatan Kota Palopo Tahun 2016. Kota Palopo, Sulawesi-Selatan. Rekart, M. L. (2015). Caring for Sex Workers. BMJ (Online), 351(August), $1-9$.

https://doi.org/10.1136/bmj.h4011

Sugiyono. (2016). Metode Penelitian

Kuantitatif, Kualitatif dan R\&D.

Bandung: Alfabeta

World Health Organization. (2013).

Baseline Report on Global Sexually transmitted Infection Surveillance 2012. The WHO Department of Reproductive Health and Research (WHO/RHR) Coordinated

Development.

http://www.who.int/research/en/

(diakses pada tanggal 17 Oktober 2018). 